\title{
Pengaruh Permintaan -Money terhadap Pendapatan per Kapita Di Indonesia
}

\author{
Mohamad Ghozali \\ Fakultas Syari'ah dan Ekonomi Islam \\ Institut Agama Islam Negeri Syekh Nurjati Cirebon \\ Email: ghozali.iaincrb@gmail.com \\ Triaji Pambudi \\ Alumni Universitas Jenderal Soedirman Purwokerto \\ Email: triajipambudi@gmail.com
}

\begin{abstract}
Abstrak
Penelitian ini bertujuan untuk menganalisis pengaruh permintaan e-money terhadap pendapatan per kapita dalam jangka panjang dan jangka pendek di Indonesia. Metode penelitian ini adalah deskriptif kuantitatif. Penelitian ini dilakukan dengan data sekunder dan waktu pengamatan tahun 2013:Q1 - 2017:Q4. Data diperoleh dari data publikasi Bank Indonesia serta Badan Pusat Statistik (BPS) Indonesia. Teknik analisis data menggunakan Error Correction Model (ECM). Hasil analisis menunjukkan bahwa dalam jangka panjang pendapatan per kapita berpengaruh positif dan signifikan terhadap permintaan e-money. Dalam jangka pendek pendapatan per kapita berpengaruh positif dan tidak signifikan permintaan e-money. Implikasi dari kesimpulan di atas yaitu pertama, pemerintah perlu melakukan sosialisasi program Bantuan Langsung Non-Tunai agar seluruh masyarakat mulai mengenal instrumen non-tunai. Kedua, Bank Indonesia perlu memperhatikan sistem interkoneksi mesin reader serta memperhatikan banyaknya uang kartal yang beredar agar dapat terwujudnya less cash society.
\end{abstract}

Kata kunci: E-money, uang, Pendapatan per Kapita, Error Correction Model.

\begin{abstract}
This research aims to analyze the effect of e-money demand on per capita income in the long and short term in Indonesia. This research method is quantitative descriptive. This research was conducted with secondary data and observation time in 2013: Q1 - 2017: Q4. Data was obtained from Bank Indonesia publication data and the Indonesian Central Statistics Agency (BPS). Data analysis techniques using Error Correction Model (ECM). The results of the analysis show that in the long run per capita income has a positive and significant effect on e-money demand. In the short term, per capita income has a positive and insignificant effect on e-money demand. The implication of the conclusions above is that first, the government needs to disseminate the Non-Cash Direct Aid program so that all people begin to recognize non-cash instruments. Secondly, Bank Indonesia needs to pay attention to the interconnection system of the reader machine and pay attention to the amount of currency circulating in order to realize a less cash society.
\end{abstract}

Keywords: E-money, money, Gross Domestic Product, Error Correction Model 


\section{Pendahuluan}

Akhir tahun 2015 lalu Masyarakat Ekonomi ASEAN (MEA) resmi diberlakukan, ini berarti akan banyak barang dan jasa yang masuk dan keluar Indonesia. Salah satu sektor yang terasa perubahannya adalah sektor keuangan terutama perbankan. Pengalaman Indonesia dengan terjadinya krisis nilai tukar sejak pertengahan tahun 1997 betapa pentingnya menjaga dan mencapai stabilitas keuangan (Veithzal et al, 2013). Sistem pembayaran tunai berkembang dari commodity money sampai fiat money, sementara sistem pembayaran non-tunai berkembang dari yang berbasis warkat seperti cek dan bilyet giro sampai kepada yang berbasis elektronik seperti kartu dan electronic money (Sri dan Ascarya, 2003). Untuk mengikuti perkembangan zaman, perbankan mulai melakukan inovasi cara pembayaran. Salah satu inovasinya adalah dengan menerbitkan e-money untuk mempermudah masyarakat dalam melakukan transaksi mikro.

Uang adalah persediaan yang dapat dengan segera digunakan untuk melakukan transaksi (Mankiw, 2006). Sejalan perkembangan perekonomian dari waktu ke waktu, bentuk uang semakin bervariasi. Uang kertas dan uang logam yang juga disebut sebagai uang kartal, kemudian dilengkapi dengan uang giral dalam bentuk cek dan bilyet giro. Uang kartal dapat juga disebut sebagai uang tunai, yaitu dapat langsung digunakan sebagaimana fungsi uang. Manfaat yang didapat ketika menggunakan uang tunai adalah melakukan transaksi secara spontan tanpa perlu alat bantu dalam melakukan sebuah transaksi. Adapun uang tunai juga memiliki kelemahan yaitu kurang efisien dalam melakukan transaksi seperti harus bertemu secara face to face antara penjual dan pembeli, membutuhkan tempat yang besar dalam penyimpanannya apabila dalam nominal yang besar, serta kurangnya keamanan dalam melakukan transaksi dengan nominal yang besar. Menurut Layaman dan Andriyani (2017) tidak dapat dipungkiri bahwa teknologi khususnya tekologi perbankan memaksa industri perbankan untuk memefomulasi ulang strategi teknologi informasi yang mereka terapkan untuk bisa bersaing.

Tugas Bank Indonesia di bidang sistem pembayaran mencakup sistem pembayaran tunai dan non-tunai. Dalam tugasnya di bidang sistem pembayaran tunai, Bank Indonesia bertanggungjawab dalam mengeluarkan dan mengedarkan uang Rupiah dalam jumlah yang cukup. Hal ini melihat bahwa jumlah penduduk Indonesia yang banyak serta kondisi geografis yang sangat luas menjadi masalah tersendiri yang dihadapi Bank Indonesia. Selain itu, penggunaan uang tunai sebagai alat pembayaran mulai menimbulkan masalah. Masalah yang muncul seperti tingginya biaya cash handling, resiko perampokan atau pencurian, dan beredarnya uang palsu meskipun sebagian masyarakat menganggap bahwa uang tunai merupakan alat pembayaran yang bebas biaya, praktis, dan efisien. Di sisi lain berdasarkan sudut pandang perekonomian secara luas, penggunaan uang tunai dalam jumlah yang sangat besar dan dalam jangka panjang akan menimbulkan biaya yang berkaitan dengan cash handling dan rendahnya velocity of money (Ahmad et al, 2006). Jika uang tunai yang beredar jumlahnya sangat banyak, hal ini mengindikasikan bahwa bank sentral selaku penerbit uang tunai mengeluarkan biaya pencetakan uang yang sangat mahal. Selain itu, karena letak geografis Indonesia yang sangat luas hal ini menjadi penyebab perputaran uang tunai hanya berada di kotakota yang dekat dengan bank sentral sehingga berdampak pada rendahnya velocity of money.

E-money adalah salah satu alternatif alat pembayaran non-tunai selain kartu debet dan kartu kredit. Kemunculan e-money ditunjukkan dengan adanya Peraturan Bank Indonesia Nomor 16/8/PBI/2014 tentang perubahan atas Peraturan Bank Indonesia Nomor 11/12/PBI/2009 tentang Uang Elektronik. E-money menawarkan beberapa kemudahan seperti kepraktisan, kemudahan, dan kecepatan dalam melakukan transaksi, 
hadirnya e-money dapat menekan biaya pencetakan uang tunai, serta dapat meminimalisir kejahatan kriminal, dan menekan potensi kehilangan angka yang terekam dalam produk domestik bruto. Andriani (2016) menyatakan bahwa kenyamanan transakasi merupakan faktor penting yang dipertimbangkan untuk digunakan dalam sistem pembayaran di Indonesia, pengguna e-money merasa nyaman karena dapat melakukan pembayaran e-money yang dapat digunakan untuk membayar tol, parkir, belanja di minimarket dan tempat lainnya yang telah menggunakan EDC untuk memproses pembayaran dengan $e$-money.

E-money juga memiliki beberapa kekurangan yaitu belum semua transaksi bisa memakai e-money karena e-money baru bisa dipakai di merchant yang bekerja sama dengan penerbit, resiko seluruh uang hilang ketika pengguna kehilangan kartu, sulitnya mengecek saldo menjadi kekurangan menggunakan e-money, serta terjadinya kegagalan pada sistem saat melakukan transaksi. Menurut Ferry et al (2009) dampak pembayaran non-tunai akan menyebabkan efek subtitusi dan efisiensi. Efek subtitusi terjadi dari uang kartal (mengalami penurunan) ke M1 dan M2 (mengalami kenaikan). Kenaikan M1 dan M2 tersebut akan menyebabkan turunnya BI rate, yang dapat mendorong peningkatan produk domestik bruto (PDB). Sementara itu efek efisiensi adanya peningkatan pembayaran non-tunai terjadi dari sisi biaya transaksi. Hal tersebut tentunya akan menekan inflasi.

Penggunaan instrumen pembayaran non-tunai di Indonesia masih relatif rendah, pada tahun 2015 total nominal transaksi $e$ money sebesar Rp5.283.018.000.000,dibandingkan negara tetangga seperti Thailand sebesar 67.616.610.000 Thai Baht atau Rp25.156.083.584.400 (1 thai baht = Rp372,04) dan Malaysia sebesar 5.995.000.000 Ringgit Malaysia atau Rp18.672.326.750.000 (1 ringgit = Rp3.114,65). Walaupun demikian pada tahun 2014 penggunaan instrumen pembayaran non-tunai mengalami peningkatan sebesar 16,7 persen, apabila dibandingkan dengan tahun 2013 (Bank Indonesia, 2014). Dalam ketentuan Peraturan Bank Indonesia Nomor 11/12/PBI/2009 tentang Uang Elektronik (Electronic Money) dalam ketentuan Pasal 1 Ayat 3, "Uang Elektronik (Electronic Money) adalah alat pembayaran yang diterbitkan atas dasar nilai uang yang disetor terlebih dahulu oleh pemegang kepada penerbit".

Pendapatan masyarakat menjadi salah satu faktor selain jumlah uang beredar dan perputaran uang yang dapat memengaruhi permintaan e-money. Menurut Badan Pusat Statistik (2015) pendapatan penduduk Indonesia tercermin dalam pendapatan nasional per kapita. Pada tahun 2014 pendapatan nasional per kapita sebesar Rp31.360.272,7 dan mengalami kenaikan sebesar 5,23 persen pada tahun 2015 menjadi Rp32.999.518,1. Menurut Aula dan Maimun (2016) perkembangan penggunaan sistem pembayaran elektronik akan meningkatkan kemudahan transaksi yang akan mendorong penurunan biaya transaksi dan dapat menstimulus pertumbuhan ekonomi. Dengan demikian besarnya pendapatan masyarakat akan memengaruhi penggunaan e-money dikalangan masyarakat. Seperti halnya pada penelitian Lasondy dan Syarief (2016) variabel e-money, SKNBI, dan BI-RTGS berpengaruh positif signifikan terhadap M1 baik dalam jangka pendek maupun jangka panjang. Pun juga Mbuguah dan Karume (2013) Automated Teller Machine (ATM) dan Mobile money transfer memiliki trend positif singnifikan terhadap transfer uang elektronik di Kenya.

Perkembangan e-money di Indonesia yang baru diluncurkan tahun 2007, sedikit terlambat jika dibandingkan dengan negara Thailand (tahun 2004) dan Malaysia (tahun 2003) dalam menyosialisasikan GNNT. Nominal transaksi e-money sebesar Rp5.283.018.000.000,- dibandingkan negara tetangga seperti Thailand sebesar 67.616.610.000 Thai Baht atau Rp25.156.083.584.400 (1 thai baht = Rp372,04) dan Malaysia sebesar 
5.995.000.000 Ringgit Malaysia atau Rp18.672.326.750.000 (1 ringgit = Rp3.114,65), Indonesia masih jauh tertinggal. Menurut Rahman dan Zaki (2014) jika dilihat secara umum, kelompok masyarakat berpenghasilan tinggi berpotensi menggunakan instrumen pembayaran nontunai (tidak hanya e-money) bila dibandingkan dengan kelompok masyarakat yang berpenghasilan rendah.

\section{Pembahasan}

\section{Teori Permintaan Uang Modern}

Teori penawaran uang modern atau sistem standar kertas dikembangkan oleh ekonom-ekonom setelah Keynes. Dalam sistem standar kertas, sumber dari terciptanya uang beredar adalah otoritas moneter (pemerintah dan bank sentral) dan lembaga keuangan (sistem moneter). Otoritas moneter merupakan penyalur uang inti atau uang primer, sedangkan lembaga keuangan (perbankan) merupakan penyalur uang sekunder bagi masyarakat. Proses terciptanya uang beredar merupakan proses pasar artinya hasil interaksi antara permintaan dan penawaran dan bukan sekedar pencetakan uang atau keputusan pemerintah saja. Dalam teori penawaran uang modern, terjadi sebuah proses penyesuaian keseimbangan antara permintaan dan penawaran uang yang disebut pelipat uang atau money multiplier. Dalam kenyataannya uang yang diciptakan bank, tidak hanya tergantung pada kemauan bank semata, tetapi tergantung pula pada hasil interaksi para pelaku pasar uang.

Menurut Mankiw (2006) Fungsi uang terdiri dari tiga fungsi, yaitu:

a. Medium pertukaran

Uang merupakan alat pembayaran yang sah dalam melakukan transaksi ekonomi. Uang berfungsi mempermudah dalam melakukan transaksi ekonomi, yaitu berperan sebagai medium pertukaran untuk mendapatkan suatu jasa dan barang yang diinginkan para pelaku ekonomi. Seperti pada penelitian Suliman dan Dafalla (2011) yang menyatakan bahwa dalam jangka panjang adanya pengaruh positif antara permintaan uang riil dengan pendapatan riil namun pada variabel inflasi dan tingkat nilai tukar memiliki pengaruh yang negatif dengan permintaan uang riil.

b. Penyimpan nilai

Uang sebagai penyimpan nilai dapat diartikan mengalihkan daya beli di masa sekarang untuk di masa yang akan datang. Disaat masyarakat mendapatkan uang, maka masyarakat dapat menyisihkan sebagian dari pendapatannya untuk disimpan dan dipergunakan di kemudian hari.

c. Satuan hitung

Uang adalah ukuran yang kita gunakan untuk mengukur suatu harga dari barang dan jasa dalam transaksi ekonomi. Uang menunjukkan nilai suatu barang dan jasa yang diperjualbelikan, serta uang dapat mengukur tingkat kekayaan yang dimiliki para pelaku ekonomi.

Pengertian jumlah uang beredar (JUB) secara sederhana ialah jumlah uang yang tersedia. Dalam perekonomian yang menggunakan uang komoditas, jumlah uang beredar adalah jumlah dari komoditas itu. Kontrol atas jumlah uang beredar disebut kebijakan moneter. Di Indonesia, kebijakan moneter didelegasikan kepada Bank Indonesia sebagai bank sentral di Indonesia (Mankiw, 2006).

Menurut Nopirin (1992) jumlah uang beredar terdiri atas: (a) uang kartal yang beredar di Luar Bank Indonesia, bank-bank umum serta di luar Kantor Bendahara Negara, dan (b) saldo giro atau rekening koran yang bukan miliknya bank umum, pemerintah serta penduduk. Jumlah uang kartal dan giral tersebut disebut uang beredar dalam arti sempit $\left(\mathbf{M}_{1}\right)$ dan apabila jumlah tersebut ditambah dengan uang kuasi (terdiri dari deposito berjangka yang belum jatuh tempo, tabungan dan simpanan dalam valuta asing milik penduduk yang disimpan di bank umum) disebut uang beredar dalam arti luas $\left(\mathrm{M}_{2}\right)$.

Sementara itu, definisi uang beredar di berbagai negara dapat bervariasi sesuai dengan kondisi sektor keuangan dan 
perbankan serta kebutuhan otoritas moneter negara yang bersangkutan. Di Amerika Serikat misalnya, definisi uang beredar tidak hanya $\mathrm{M}_{1}$ dan $\mathrm{M}_{2}$ namun juga $\mathrm{M}_{3}$ (Solikin dan Suseno, 2002).

Mankiw (2006) mengatakan bahwa terdapat tiga model jumlah uang beredar, model jumlah uang beredar ini di bawah cadangan-fraksional perbankan. Model tersebut mempunyai tiga variabel eksogen yaitu pertama, basis moneter (monetary base) adalah jumlah uang yang dipegang publik sebagai mata uang dan oleh bank sebagai cadangan, saldo basis moneter ini langsung dikendalikan oleh Bank Sentral. Kedua, rasio deposito-cadangan (reservedeposit ratio) adalah bagian deposito yang bank cadangkan, rasio deposito-cadangan ditentukan oleh kebijakan bisnis bank dan undang-undang perbankan. Ketiga, rasio deposito-uang kartal (currency-deposit ratio) adalah jumlah uang kartal atau mata uang yang dipegang orang dalam bentuk rekening giro, rasio deposito-uang kartal mencerminkan preferensi rumah tangga terhadap bentuk mata uang yang akan mereka pegang.

Kajian yang dilakukan oleh Siti et al (2006) dengan belum dimasukkannya perhitungan float ke dalam definisi M1 maka diasumsikan bahwa kebijakan menurunkan jumlah uang beredar akan mendorong masyarakat untuk berpindah menjadi pengguna $e$-money.

\section{Uang Elektronik (e-Money)}

Pengertian uang

elektronik

(electronic money) menurut Peraturan Bank Indonesia No. 16/8/PBI/2014 adalah nilai uang yang disimpan secara elektronik pada suatu media server atau chip yang dapat dipindahkan untuk kepentingan transaksi pembayaran dan/atau transfer dana. Menurut Peraturan Bank

Indonesia No.11/12/PBI/2009 Tanggal 13 April 2009 tentang Uang Elektronik (Electronic Money) dan juga perubahannya yaitu pada Peraturan Bank Indonesia No. 16/8/PBI/2014, uang elektronik harus memenuhi unsur-unsur sebagai berikut, yaitu: (1) Diterbitkan atas dasar nilai uang yang disetor terlebih dahulu oleh pemegang kepada penerbit; (2) Nilai uang disimpan secara elektronik dalam suatu media seperti server atau chip; (3) Digunakan sebagai alat pembayaran kepada pedagang yang bukan merupakan penerbit uang elektronik tersebut; (4) Nilai uang elektronik yang disetor oleh pemegang dan dikelola oleh penerbit bukan merupakan simpanan sebagaimana dimaksud dalam undang-undang yang mengatur mengenai perbankan.

Bank Indonesia mengatur ada batasan nilai maksimal yang diperkenankan dalam satu kartu e-money. Dalam Peraturan Bank Indonesia nomor 11/12/PBI/2009 tentang Uang Elektronik (Electronic Money) diatur bahwa besaran nilai maksimal dalam $e$ money adalah sebesar Rp1.000.000,-. Ini merupakan upaya dari bank sentral untuk menurunkan tingkat risiko yang ditanggung oleh pengguna e-money. Pada Peraturan Bank Indonesia No. 16/8/PBI/2014 juga menjelaskan bahwa berdasarkan pencatatan data identitas pemegang, uang elektronik dapat dibedakan menjadi 2 (dua) jenis, yaitu (1) Uang elektronik yang data identitas pemegangnya terdaftar dan tercatat pada penerbit (registered); dan (2) Uang elektronik yang data identitas pemegangnya tidak terdaftar dan tidak tercatat pada penerbit (unregistered). Melalui surat edaran Bank Indonesia No. 11/11/DASP tanggal 13 April 2009 tentang jenis-jenis uang elektronik memiliki perbedaan dengan penjabaran sebagai berikut dipaparkan pada Tabel 1.

Tabel 1. Persamaan dan Perbedaan Uang Elektronik Jenis Terdaftar dan Tidak Terdaftar

\begin{tabular}{|c|c|c|}
\hline Kriteria & $\begin{array}{l}\text { Terdaftar } \\
\text { (registered) }\end{array}$ & $\begin{array}{c}\text { Tidak } \\
\text { Terdaftar } \\
\text { (unregistered) }\end{array}$ \\
\hline $\begin{array}{l}\text { Pencatatan } \\
\text { Pemegang } \\
\text { Indetitas }\end{array}$ & $\begin{array}{lr}\text { Data identitas } \\
\text { pemegang kartu } \\
\text { elektronik } \\
\text { tercatat dan } \\
\text { terdaftar pada }\end{array}$ & $\begin{array}{lr}\text { Data } & \text { identitas } \\
\text { pemegang kartu } \\
\text { uang } \\
\text { tidak lektronik } \\
\text { pada tercatat } \\
\end{array}$ \\
\hline
\end{tabular}




\begin{tabular}{|c|c|c|}
\hline & penerbit & $\begin{array}{l}\text { tidak harus } \\
\text { menjadi nasabah } \\
\text { penerbit }\end{array}$ \\
\hline $\begin{array}{l}\text { Nilai } e- \\
\text { money yang } \\
\text { tersimpan }\end{array}$ & $\begin{array}{l}\text { Batas nilai uang } \\
\text { elektronik yang } \\
\text { tersimpan dalam } \\
\text { media } \\
\text { chip/server } \\
\text { paling banyak } \\
\text { sebesar } \\
\text { Rp5.000.000 } \\
\text { (lima juta } \\
\text { rupiah) }\end{array}$ & $\begin{array}{l}\text { Batas nilai uang } \\
\text { elektronik yang } \\
\text { tersimpan dalam } \\
\text { media } \\
\text { chip/server } \\
\text { paling banyak } \\
\text { sebesar } \\
\text { Rp1.000.000 } \\
\text { (satu juta rupiah) }\end{array}$ \\
\hline $\begin{array}{l}\text { Batas nilai } \\
\text { transaksi }\end{array}$ & $\begin{array}{l}\text { Dalam satu } \\
\text { bulan setiap } \\
\text { uang elektronik } \\
\text { secara } \\
\text { keseluruhan } \\
\text { ditetapkan } \\
\text { paling banyak } \\
\text { transaksi sebesar } \\
\text { Rp20.000.000 } \\
\text { (dua puluh juta } \\
\text { rupiah) }\end{array}$ & $\begin{array}{l}\text { Dalam satu } \\
\text { bulan setiap } \\
\text { uang elektronik } \\
\text { secara } \\
\text { keseluruhan } \\
\text { ditetapkan } \\
\text { paling banyak } \\
\text { transaksi sebesar } \\
\text { Rp20.000.000 } \\
\text { (dua puluh juta } \\
\text { rupiah) }\end{array}$ \\
\hline $\begin{array}{l}\text { Jenis } \\
\text { transaksi } \\
\text { yang dapat } \\
\text { digunakan }\end{array}$ & $\begin{array}{l}\text { Meliputi } \\
\text { transaksi } \\
\text { pembayaran, } \\
\text { transfer dana, } \\
\text { dan fasilitas } \\
\text { transaksi lainnya } \\
\text { yang disediakan } \\
\text { oleh penerbit }\end{array}$ & $\begin{array}{l}\text { Meliputi } \\
\text { transaksi } \\
\text { pembayaran, } \\
\text { transfer dana, } \\
\text { dan fasilitas } \\
\text { transaksi lainnya } \\
\text { yang disediakan } \\
\text { oleh penerbit }\end{array}$ \\
\hline
\end{tabular}

Sumber : Bank Indonesia, 2016

\section{Pendapatan Per Kapita}

Produk domestik bruto (PDB) sering dianggap sebagai ukuran terbaik dari kinerja perekonomian. Tujuan dari Produk Domestik Bruto (PDB) adalah meringkas aktivitas ekonomi dalam suatu nilai uang tertentu selama periode waktu tertentu. Ada dua cara untuk mengukur nilai aktivitas ekonomi. Pertama dengan melihat PDB sebagai pendapatan total dari setiap orang di dalam perekonomian. Kedua PDB dapat dilihat sebagai pengeluaran total atas output barang dan jasa perekonomian (Mankiw, 2006).

Menurut Mudrajad (2006) kenaikan pendapatan per kapita (gross national product (GNP) riil dibagi jumlah penduduk) dan kenaikan pendapatan nasional riil menyiratkan bahwa perhatian pembangunan bagi negara miskin adalah menurunkan tingkat kemiskinan. Pendapatan nasional riil (atau GNP pada harga konstan) yang meningkat seringkali tidak diikuti dengan perbaikan kualitas hidup. Bila pertumbuhan penduduk melebihi atau sama dengan pertumbuhan pendapatan nasional maka pendapatan per kapita bisa menurun atau tidak berubah. Berdasarkan penelitian yang dilakukan oleh Arsita (2015) jika seseorang memiliki pendapatan yang tinggi maka akan meningkatkan minat menggunakan $e$-money.

\section{Kerangka Pemikiran}

Perkembangan teknologi dan informasi memberikan dampak dalam bidang sistem pembayaran khususnya sistem pembayaran mikro sampai ritel, salah satunya adalah dengan munculnya instrumen pembayaran yang disebut e-money. Menurut Siti et al (2006) penggunaan e-money sebagai alternatif alat pembayaran non-tunai di beberapa negara menunjukkan adanya potensi yang cukup besar untuk mengurangi tingkat pertumbuhan penggunaan uang tunai.

Pendapatan masyarakat yang dicerminkan oleh pendapatan per kapita juga berpengaruh dalam menggunakan e-money, ketika pendapatan per kapita meningkat maka pengeluaran akan meningkat yang mengakibatkan masyarakat tertarik menggunakan e-money dikarenakan praktis dan cepat dalam melakukan pembayaran. Berdasarkan penelitian Arista (2015) jika sesorang memiliki pendapatan yang tinggi maka akan meningkatkan minat menggunakan e-money. Selain itu, jumlah uang beredar dalam arti sempit (M1) dimana ketika mayoritas masyarakat menggunakan $e$-money maka penggunaan uang tunai akan berkurang dan peredaran uang akan meningkat. Sejalan dengan penelitian yang dilakukan oleh Siti et al (2006) bahwa kebijakan menurunkan jumlah uang beredar akan mendorong masyarakat untuk berpindah menjadi pengguna $e$-money.

\section{Hipotesis Penelitian}

Pendapatan per kapita didapatkan dari hasil pembagian pendapatan nasional suatu negara dengan jumlah penduduk negara tersebut. Pendapatan per kapita juga merefleksikan PDB per kapita (Todaro, 
2006). Sementara itu, Mudrajad (2006) mengatakan bahwa kenaikan pendapatan per kapita (gross national product (GNP) riil dibagi jumlah penduduk) dan kenaikan pendapatan nasional riil menyiratkan bahwa perhatian pembangunan bagi negara miskin adalah menurunkan tingkat kemiskinan.

Berdasarkan penelitian yang dilakukan oleh Arista (2015) jika seseorang memiliki pendapatan yang tinggi maka akan meningkatkan minat menggunakan e-money. Berdasarkan uraian diatas maka dapat dirumuskan hipotesis ketiga sebagai berikut: Permintaan e-money berpengaruh positif dan signifikan terhadap Pendapatan per kapita.

\section{Metodologi Penelitian Jenis Penelitian}

Penelitian ini menggunakan metode deskriptif kuantitatif. Penelitian kuantitatif dapat diartikan sebagai penelitian yang disajikan dengan angka-angka mulai dari pengumpulan data, penafsiran terhadap data, dan penampilan hasilnya (Suharsimi, 2006).

\section{Jenis dan Sumber Data}

Jenis data yang digunakan dalam penelitian ini adala data sekunder. Data sekunder yaitu data yang diperoleh dalam bentuk yang sudah dikumpulkan dan diolah oleh pihak lain (Syahirman dan Umiyati, 2009). Sumber data sekunder yang digunakan dalam penelitian ini yaitu berasal dari sebagai berikut:

a. Permintaan e-money di Indonesia berupa nominal transaksi diperoleh dari Statistik Sistem Pembayaran Uang Elektronik melalui website resmi $\mathrm{BI} \mathrm{di}$ www.bi.go.id

b. Pendapatan per kapita diperoleh dari data Ekonomi melalui website resmi Badan Pusat Statistik di www.bps.go.id

\section{Metode Pengumpulan Data}

Metode pengumpulan data yang digunakan dalam penelitian adalah metode kepustakaan (library research), yaitu penelitian yang dilakukan dengan mengumpulkan literatur berupa jurnal ilmiah, artikel ilmiah, dan buku-buku yang berkaitan dengan perkembangan e-money dan pendapatan per kapita.

\section{Teknik Analisis Data}

Metode penelitian yang digunakan dalam penelitian ini adalah Error Correction Model (ECM) karena dalam analisis ekonometrika untuk data runtun waktu, ECM memiliki kemampuan untuk menganalisis fenomena ekonomi jangka panjang dan mengkaji kekonsistenan model empirik dengan teori ekonometrika. Selain itu model linier dinamik dapat dipakai untuk menjelaskan mengapa pelaku ekonomi menghadapi adanya ketidakseimbangan (disequilibrium) dalam konteks bahwa fenomena yang diinginkan (desired) oleh pelaku ekonomi belum tentu sama dengan apa yang senyatanya (actual) yang dihadapi antar waktu (Insukindro, 1999).

Adapun beberapa tahapan analisis yang dilakukan ialah pertama, uji akar unit (Unit Root Test) untuk mengetahui apakah data tersebut stasioner atau tidak. Ada tidaknya akar unit dapat diketahui dengan menggunakan Augmented Dickey Fuller $(A D F)$ Test. Kedua, uji kointegrasi untuk mengetahui adanya hubungan jangka panjang dan meramalkan keseimbangannya dengan menggunakan Engle-Granger Cointegration Test. Ketiga, melakukan koreksi kesalahan (error correction) dengan menggunakan ECM untuk model yang digunakan.

\section{Hasil dan Pembahasan \\ Gambaran Umum Variabel Penelitian}

1. Perkembangan $e$-Money di Indonesia Periode 2013-2017

Bank Indonesia telah mengkaji penggunaan $e$-money sejak tahun 2000. Pada tahun 2006 dilanjutkan dengan membahas mengenai operasional e-money dilihat dari aspek secara teknis maupun non-teknis (Sumolang, 2015). Pada tahun 2007 e-money hadir dikalangan masyarakat dan tahun 2009 e-money telah diresmikan oleh Bank 
Indonesia. Perkembangan e-money di Indonesia dapat dilihat pada Gambar 1.

Gambar 1. Perkembangan E-Money Periode 2013:Q1 $-2017: \mathrm{Q} 4$

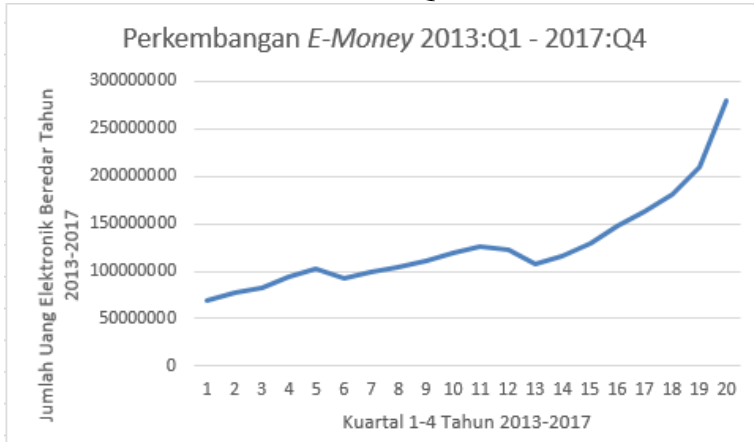

Sumber : Bank Indonesia, 2015

Gambar 1 menunjukkan perkembangan uang elektronik dari tahun 2013 sampai dengan 2017 yang ditunjukkan oleh nilai transaksi e-money.

Fokus kebijakan Bank Indonesia dalam sistem pembayaran selama tahun 2013 adalah peningkatan kemanan, efisiensi, penguatan insfrastruktur sistem dan interkoneksi antar infrastruktur sistem pembayaran. Hal yang melatarbelakangi kebijakan tersebut adalah semikin tingginya transasksi pembayaran yang dilakukan melalui sistem pembayaran. Pesatnya perkembangan instrument pembayaran yang berbasis teknologi secara berangsur-angsur mendorong masyarakat untuk beralih menuju pembayaran non-tunai, khususnya di kotakota besar, meskipun penggunaan fisik uang sampai saat ini masih banyak digunakan sebagai alat pembayaran (Laporan Perekonomian Indonesia, 2012). Pada tahap awal, implementasi interkoneksi e-money dilakukan pada sektor transportasi karena terkait dengan kebutuhan masyarakat dan telah terbukti keberhasilannya di beberapa negara maju (Laporan Tahunan, 2012).

Pada tahun 2012, efisiensi kebijakan interoperabilitas dalam sistem pembayaran ritel diawali dengan menghubungkan jaringan ATM Bank Central Asia dan Bank Mandiri semakin memudahkan masyarakat dalam melakukan transaksi pembayaran dengan menggunakan kartu. Melalui kebijakan ini $e$-money diharapkan juga dapat meningkatakan efisiensi secara nasional karena hanya dengan cukup satu kartu, masyarakat dapat melakukan berbagai transaksi pembayaran diberbagai pedagang yang bekerjasama dengan seluruh penerbit $e$ money (Laporan Perekonomian Indonesia, 2013). Pada tahun 2013, peningkatan transaksi e-money didorong oleh perkembangan sistem pembayaran ritel berbasis non-tunai serta peningkatan konsumsi masyarakat yang lebih tinggi dibandingkan dengan tahun 2012 (Laporan Perekonomian Indonesia, 2014).

Pada tahun 2014 peningkatan nilai transaksi menggunakan e-money telah dilakukan oleh Bank Indonesia dan industri, upaya yang telah ditempuh antara lain pengembangan kawasan non-tunai, penyempurnaan ketentuan e-money, serta interkoneksi e-ticketing pada Transjakarta dan kereta commuter. Salah satu ketentuannya adalah penyelenggaraan Layanan Keuangan Digital (LKD). Layanan keuangan digital adalah layanan jasa sistem pembayaran dan keuangan yang dilakukan melalui kerjasama dengan pihak ketiga dan menggunakan sarana serta perangkat teknologi berbasis mobile maupun berbasis web dalam rangka keuangan inklusif. Pihak ketiga berupa agen individu yang bertindak atas nama bank memfasilitasi pembukaan rekening, melayani tarik dan setor tunai, serta pembayaran tagihan dan billing (Laporan Perekonomian Indonesia, 2015). Pada tahun 2015 setelah diluncurkan program Layanan Keuangan Digital (LKD), program tersebut berkembang cukup baik dengan telah hadirnya LKD di seluruh provinsi di Indonesia. Perkembangan positif tersebut tercermin dari bertambahnya bank penyelenggara LKD dan jumlah agen LKD. Sampai dengan Desember 2015, penyelenggara LKD sebanyak 5 bank dengan jumlah agen LKD yang melayani masyarakat mencapai 69.548 agen dan menjangkau 461 Kabupaten/Kota di Indonesia dan berdampak terhadap bertambahnya nilai transaksi $e$ money (Laporan Perekonomian Indonesia, 2016). 
Pada tahun 2013, penyedia jasa $e$ money berlomba-lomba untuk memberi kemudahan dan kenyamanan bagi konsumennya dalam melakukan transaksi, tercatat 17 penerbit e-money berizin di Indonesia baik yang menggunakan server based maupun chip based. E-money pertama kali diterbitkan oleh BCA pada tahun 2007. Sampai tahun 2013 industri usaha e-money didominasi oleh industri bank dan perusahaan telekomunikasi (Laporan Perekonomian Indonesia, 2014). Pada tahun 2014 Bank Indonesia telah melakukan sosialisasi melalui Gerakan Nasional NonTunai (GNNT) sehingga menyebabkan peningkatan ketersediaan jumlah mesin EDC di Indonesia. Di tahun 2014 terdapat dua penambahan penerbit, sehingga menjadi 19 penerbit, peningkatan jumlah penerbit sejalan dengan jumlah pemegang e-money dan infrastruktur. Penerbit e-money didominasi oleh lembaga selain bank sebanyak 10 penerbit dan 9 penerbit berasal dari bank umum konvensional (Laporan Perekonomian Indonesia, 2015). Pada tahun 2015, Bank Indonesia melakukan pilot project dengan melibatkan 3 perusahaan jasa telekomunikasi sebagai penyelenggara LKD dan komunitas pesantren sebagai agen LKD. Pertimbangan melibatkan jasa telekomunikasi karena telah terbiasa melayani pasar, unggul dalam teknologi komunikasi, dan memiliki aplikasi uang elektronik yang menyatu dengan nomor telepon (Laporan Perekonomian Indonesia, 2016). Pada sisi sistem pembayaran nontunai, kebijakan Bank Indonesia dirumuskan ke dalam tiga besaran strategi, yaitu: (i) mendorong interkoneksi dan interoperabilitas instrumen dan kanal pembayaran ritel domestik di bawah payung Gerbang Pembayaran Nasional (GPN); (ii) memperluas program elektronifikasi; dan (iii) merespons perkembangan ekonomi digital secara berimbang. Ketiga besaran strategi ini didukung oleh pelaksanaan fungsi pengawasan di bidang sistem pembayaran (Laporan Perekonomian Indonesia, 2017).

\section{Pendapatan Per Kapita Penduduk Indonesia Periode 2013-2017}

Pendapatan per kapita diperoleh dari hasil pembagian pendapatan nasional suatu negara dengan jumlah penduduk negara tersebut. Pendapatan per kapita juga digunakan sebagai ukuran tingkat pembangunan sebuah negara, semakin besar pendapatan per kapita, masyarakat akan semakin dapat menerima kemajuan sebuah sistem pembayaran di negara tersebut. Hal ini terlihat bahwa permintaan e-money Indonesia pada Gambar 2 terus mengalami peningkatan yang sejalan dengan peningkatan pendapatan per kapita Indonesia dalam Gambar 2.

Gambar 2. Perkembangan Pendapatan per kapita Periode 2013:Q1 - 2017:Q4

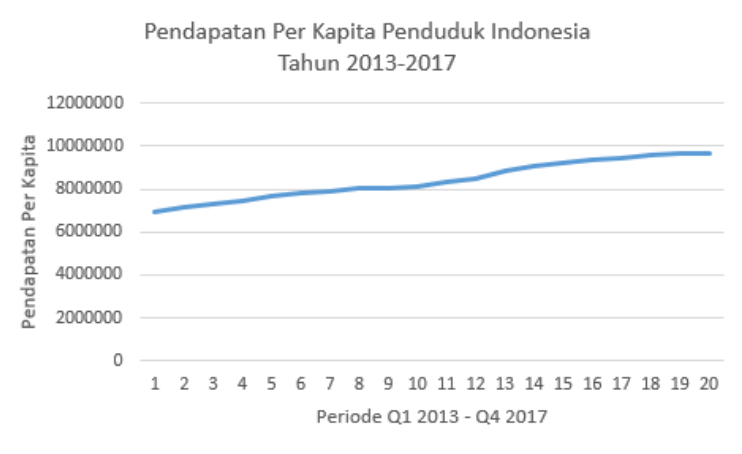

Gambar 2 menunjukkan perkembangan pendapatan per kapita Indonesia berdasarkan Badan Pusat Statistik (BPS) Indonesia. Menurut BPS (2018) pendapatan per kapita tahun 2013 sampai dengan 2017 terus mengalami kenaikan, dan besarnya kenaikan tersebut sebesar 5,23 persen per tahun secara rata-rata. Pada tahun 2014 setelah penyosialisasian GNNT oleh Bank Indonesia, masyarakat mulai tertarik menggunakan produk non-tunai tanpa melihat besarnya pendapatan yang diperoleh setiap bulannya.

\section{Pengaruh permintaan e-Money terhadap Pendapatan per Kapita di Indonesia}

Untuk melihat pengaruh variabel pendapatan per kapita terhadap permintaan e-money, digunakan error correction model (ECM). Sebelum dilakukan estimasi metode ECM, terlebih dahulu dilakukan uji 
normalitas, setelah itu dilakukan berbagai uji ECM, seperti uji akar unit atau stasioneritas, uji kointegrasi, estimasi persamaan jangka panjang, dan estimasi jangka pendek (Error Correction Model).

1) Uji Normalitas

Uji normalitas dimaksudkan untuk menguji apakah nilai residual yang telah terstandarisasi pada model regresi berdistribusi normal atau tidak. Nilai residual dikatan berdistribusi normal jika nilai residual terstandarisasi tersebut sebagian besar mendekati nilai rata-ratanya. Uji normalitas pada penelitian ini dilakukan dengan membandingkan nilai statistik Jarque-Bera (JB) dengan nilai $\mathrm{X}^{2}$ tabel. Jika nilai $\mathrm{JB} \leq \mathrm{X}^{2}$ tabel maka nilai residual terstandarisasi dinyatakan berdistribusi normal (Suliyanto, 2011). Berdasarkan hasil pengujian diperoleh nilai statistik JB sebesar 0,6363 dan nilai $X^{2}$ tabel dengan degree of freedom: 0,05, 20 adalah 31,410. Karena nilai statistik JB sebesar $(0,6363)<$ nilai $X^{2}$ tabel $(31,410)$, maka nilai residual terstandarisasi berdistribusi normal.

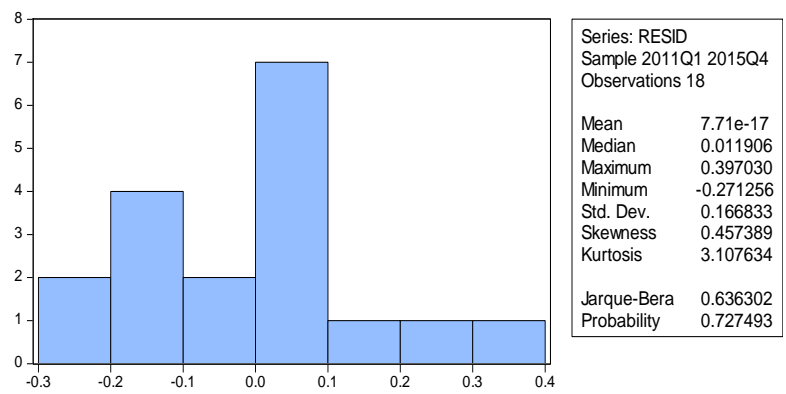

Gambar 2. Hasil Uji Normalitas data

2) Uji Akar Unit

Pengujian stasioneritas menggunakan ADF-test pada tingkat level atau derajat nol, namun variabel menunjukkan bahwa data belum stasioner pada tingkat level. Kemudian dilanjutkan uji stasioneritas pada derajat pertama, data masih menunjukkan belum stasioner pada derajat pertama. Oleh karena itu, dilanjutkan kembali pengujian stasioneritas pada derajat kedua sampai semua variabel stasioner pada derajat yang sama. Tabel hasil uji stasioneritas tingkat level dan first difference dapat dilihat pada Tabel 2 berikut:

Tabel 2. Hasil Uji Stasioneritas

Sumber : Data Olahan Eviews 7, 2018

\begin{tabular}{cccccc}
\hline Series & Prob. & Lag & $\begin{array}{c}\text { Ma } \\
x \\
\text { Lag }\end{array}$ & $\begin{array}{c}\text { Ob } \\
s\end{array}$ & $\begin{array}{c}\text { Keteranga } \\
\text { n }\end{array}$ \\
\hline D(EM,2) & $\begin{array}{c}0,001 \\
2\end{array}$ & 2 & 3 & 15 & Stasioner \\
\hline $\begin{array}{c}\text { D(PDT, } 2 \\
\text { ) }\end{array}$ & $\begin{array}{c}0,030 \\
0\end{array}$ & 0 & 3 & 17 & Stasioner \\
\hline
\end{tabular}

Tabel 2 menunjukkan bahwa setelah dilakukan uji ADF pada second difference semua variabel yang digunakan dalam penelitian ini telah stasioner pada level yang sama. Data dikatakan stasioner jika nilai probabilitas semua variabel yang diteliti kurang dari $\alpha=5 \%(0,05)$. Pada hasil uji stasioneritas menunjukkan bahwa nilai probabilitas semua variabel kurang dari 0,05. Oleh karena itu semua variabel dikatakan stasioner. Untuk selanjutnya data pada penelitian ini dapat ditulis pada model matematis seperti $\Delta \mathrm{EM}_{\mathrm{t}}=\mathrm{EM}_{\mathrm{t}}-\mathrm{EM}_{\mathrm{t}-2}$.

3) Uji Kointegrasi

Setelah data dinyatakan stasioner, selanjutnya adalah pembentukan persamaan jangka panjang dengan menggunakan Eviews.

Tabel 3. Persamaan ECM Jangka Panjang

\begin{tabular}{crrrr}
\hline Var. & Coeff. Std. Er. & t-Statistic & Prob. \\
\hline C & $-112,503$ & 19,893 & $-5,655$ & 0,0000 \\
PDT & $-1,507$ & 1,118 & $-1,347$ & 0,1966 \\
\hline \multicolumn{5}{c}{ Sumber: Data Olahan Eviews, 2016}
\end{tabular}

Berdasarkan Tabel 6, dapat diperoleh persamaan sebagai berikut:

$\operatorname{lnEM}=-112,508-1,507 \ln P D T$

F-Hitung $=160,184$

R-Squared $=0,967$

Adj R-Squared = 0,961

Pendapatan per kapita adalah hasil yang diperoleh seseorang pada periode tertentu. Nilai koefisien jangka panjang pendapatan per kapita sebesar - 1,507. Pendapatan per kapita memiliki nilai negatif yang berarti jika nilai pendapatan per kapita naik 1 persen maka akan menurunkan permintaan e-money sebesar 1,507 persen.

4) Uji Koefisien Determinasi $(R$ Squared)

Dalam model persamaan jangka panjang, untuk melihat nilai estimasi dengan dua variabel atau lebih dapat menggunakan $R$-Squared. Berdasarkan hasil estimasi 
jangka panjang pada penelitian ini, nilai $R$ Squared sebesar 0,967 atau 96,7 persen. Hal tersebut berarti variasi permintaan e-money dapat dijelaskan oleh variabel pendapatan per kapita sebesar 96,7 persen sedangkan sisanya dijelaskan oleh variabel lain yang tidak dimasukkan pada penelitian ini.

5) Uji F

Pada hasil uji $\mathrm{F}$ menurut estimasi persamaan jangka panjang dengan tingkat kepercayaan sebesar 95 persen atau $\alpha=0,05$, diperoleh nilai $\mathrm{F}_{\text {Hitung }}$ sebesar 160,184 sedangkan nilai $\mathrm{F}_{\text {Tabel }}$ sebesar 2,87 $(\mathrm{n}=20 ; \mathrm{k}=2)$ hal ini menunjukkan bahwa nilai $\mathrm{F}_{\text {Hitung }}>\mathrm{F}_{\text {Tabel }}$ atau dapat juga ditunjukkan dengan nilai probabilitasnya sebesar $0,00<0,05(\alpha=$ 0,05). Hal tersebut menunjukkan bahwa pendapatan per kapita berpengaruh signifikan terhadap variabel permintaan $e$ money.

6) Uji t

Berdasarkan hasil uji $t$ menurut estimasi persamaan jangka panjang dengan tingkat kepercayaan 95 persen atau $\alpha=0,05$ dan degree of freedom (n-k-1), dimana $\mathrm{n}=$ total sampel, $\mathrm{k}=$ total variabel independen, sehingga $20-1-1=18$. Nilai dari $\mathrm{t}_{\text {tabel }}$ sebesar 2,120, pengujian koefisien secara parsial dapat ditunjukkan dengan Tabel 4. Tabel 4. Hasil Uji t

\begin{tabular}{lcc}
\hline Variabel & $\mathrm{t}_{\text {tabel }}$ & $\mathrm{t}_{\text {hitung }}$ \\
\hline Pendapatan Per Kapita & 2,101 & 2,347477 \\
\hline
\end{tabular}

Sumber: Data Olahan Eviews, 2018

Berdasarkan Tabel 4 variabel pendapatan per kapita menunjukkan nilai $\mathrm{t}_{\text {hitung }}$ sebesar 2,347477 sedangkan nilai $t_{\text {tabel }}$ sebesar 2,120. Hal ini menunjukkan bahwa nilai $\mathrm{t}_{\text {hitung }}>\mathrm{t}_{\text {tabel }}$ yang berarti bahwa permintaan e-money berpengaruh positif dan signifikan terhadap pendapatan per kapita di Indonesia dalam jangka panjang. Signifikan berarti data sampel berhasil membuktikan pengaruh variabel permintaan e-money berpengaruh positif dan signifikan terhadap pendapatan per kapita, sehingga hipotesis Penelitian diterima.

7) Uji Kointegrasi
Uji kointegrasi dilakukan untuk memperoleh hubungan jangka panjang yang stabil antara variabel yang terintegrasi pada derajat yang sama, yaitu derajat kedua. Berdasarkan hasil uji stasioneritas, seluruh variabel dalam penelitian ini terintegrasi pada derajat kedua. Dengan demikian dapat dilakukaan uji kointegrasi. Uji kointegrasi Johansen ini digunakan untuk mengestimasi hubungan jangka panjang antara permintaan uang elektronik dengan pendapatan per kapita. Persamaan dikatakan lolos uji kointegrasi jika nilai trace statistic > critical value. Berdasarkan pengolahan data Eviews nilai trace statistic $(79,607)>$ critical value $(47,856)$. Hal ini berarti variabel pendapatan per kapita mempunyai hubungan jangka panjang dengan permintaan $e$-Money.

8) Estimasi Jangka Pendek

Error correction model digunakan untuk mengestimasi model permintaan $e$ money dinamis (jangka pendek). Estimasi persamaan jangka pendek dapat dilihat pada Tabel 5 .

Tabel 5. Persamaan ECM Jangka Pendek

\begin{tabular}{crrrl}
\hline \hline Var. & Coeff. & Std. Er & t-Stat. & Prob. \\
\hline C & $-0,082$ & 0,148 & $-0,552$ & 0,5898 \\
DDPDT & 1,244 & 3,586 & 0,347 & 0,7341 \\
RES(-2) & $-1,221$ & 0,281 & $-4,344$ & 0,0008 \\
\hline
\end{tabular}

Sumber: Data Olahan Eviews, 2016
Berdasarkan Tabel 5, dapat diperoleh persamaan sebagai berikut:

$\Delta \operatorname{lnEM}=-0,082+1,244 \quad \Delta \ln$ PDT $-1,221$

$\mathrm{ECT}_{\mathrm{t}-2}$

F-Hitung $=16,977$

$R$-Squared $=0,839$

Adj R-Squared $=0,789$

Nilai konstanta secara statistik memiliki nilai sebesar -0.082 dan tidak siginifikan dimana nilai probabilitas sebesar $0,5898>0,05(\alpha=0,05)$ yang berarti bahwa jika variabel pendapatan per kapita sama dengan nol maka besarnya permintaan $e$ money sebesar -0.082 persen.

Nilai koefisien dari ECT sebesar 1,221880, hal ini menunjukkan bahwa kecepatan ECM dalam penyesuaian 
permintaan e-money secara statistik adalah signifikan dan perbedaan antara nilai aktual permintaan e-money dengan nilai keseimbangannya sebesar 1,221880 akan disesuaikan dalam waktu satu kuartal atau sekitar tiga bulan.

Pendapatan per kapita adalah hasil yang diperoleh seseorang pada periode tertentu. Nilai koefisien jangka pendek pendapatan per kapita sebesar 1,244. Pendapatan per kapita memiliki nilai positif yang berarti jika nilai pendapatan per kapita naik 1 persen maka akan meningkatkan permintaan e-money sebesar 1,244 persen.

Variabel pendapatan per kapita memiliki pengaruh positif dan siginifikan dalam hubungan jangka panjang, serta pengaruh positif dan tidak siginifikan dalam jangka pendek. Pengaruh positif memiliki makna bahwa ketika pendapatan per kapita meningkat maka permintaan terhadap $e$ money akan meningkat pula baik dalam jangka pendek. Hal ini sesuai dengan penelitian Arista (2015) yang menemukan bahwa pendapatan yang tinggi akan menambah minat pengguna dalam menggunakan produk e-money. Berbeda dengan Sumolang (2015) yang mengatakan bahwa pemahaman masyarakat yang belum benar-benar mengerti untuk menggunakan $e$ money, selain itu masyarakat juga masih berpikir bahwa e-money merupakan barang mewah dan belum perlu digunakan jika belum memiliki pendapatan yang banyak. Sedangkan dari sisi syariah menurut Muamar (2017) lakukan proses pembayaran secara lebih cepat, mudah, efiien, dan aman. Walaupun mempunyai banyak kemanfaatan dan keunggulan, kesesuaian uang elektronik dengan maqashid syariah masih perlu didiskusikan, pasalnya uang elektronik unregistered dinilai belum sesuai dengan maqashid syariah karena uang elektronik ini tidak dilengkapi dengan PIN sehingga masih menimbulkan kemudharatan apabila kartu ini dicuri atau hilang. Menurut Rahman dan Zaki (2014) jika dilihat secara umum, kelompok masyarakat berpenghasilan tinggi berpotensi menggunakan instrumen pembayaran non-tunai (tidak hanya $e$-money) bila dibandingkan dengan kelompok masyarakat yang berpenghasilan rendah.

\section{Penutup}

Berdasarkan hasil pengujian dan pembahasan dapat ditarik kesimpulan bahwa pengaruh permintaan e-money terhadap pendapatan per kapita di Indonesia periode 2013 - 2017 adalah pendapatan per kapita berpengaruh positif dan signifkan dalam jangka panjang, dan berpengaruh positif tetapi tidak signifikan dalam jangka pendek. Implikasi dari kesimpulan di atas yaitu pertama, pemerintah perlu melakukan sosialisasi program Bantuan Langsung NonTunai agar seluruh masyarakat mulai mengenal instrumen non-tunai. Kedua, Bank Indonesia perlu memperhatikan sistem interkoneksi mesin reader serta memperhatikan banyaknya uang kartal yang beredar agar dapat terwujudnya less cash society.

\section{Daftar Pustaka}

Ahmad Hidayat. dkk. 2006. Upaya Meningkatkan Pengunaan Alat Pembayaran Non Tunai Melalui Pengembangan E-Money. Bank Indonesia. Jakarta.

Andriani Widiastuti. 2016. Penggunaan Sistem Pembayaran Elektronik Untuk Pembayaran Transportasi Umum Di JABODETABEK: Studi Kasus Pengguna Electronic Ticketing Transjakarta dan Commuter Line. Jurnal Ilmiah. Fakultas Ekonomi dan Bisnis Universitas Brawijaya. Malang.

Arista Ika Adiyanti. 2015. Pengaruh Pendapatan, Manfaat, Kemudahan Penggunaan, Daya Tarik Promosi, dan Kepercayaan Terhadap Minat Menggunakan Layanan E-Money. Jurnal Ilmiah. Jurusan Ilmu Ekonomi Universitas Brawijaya. Malang.

Badan Pusat Statistik. 2016. Pendapatan Nasional Indonesia 2011-2015. Jakarta.

2018. Pendapatan Nasional

Indonesia 2013-2017. Jakarta. 
Bank Indonesia. 2014. Memperkokoh Stabilitas, Mempercepat Reformasi Struktural untuk Memperkuat Fundamental Ekonomi: Laporan Perekonomian Indonesia. Jakarta. . 2014. Peraturan Bank Indonesia Nomor 16/8/PBI/2014 tentang perubahan atas Peraturan Bank Indonesia Nomor 11/12/PBI/2009 tentang Uang Elektronik. Bank Indonesia. Jakarta.

2012. Laporan Perekonomian Indonesia Tahun 2011. Bank Indonesia.

2013. Laporan Perekonomian Indonesia Tahun 2012. Bank Indonesia. 2014. Laporan Perekonomian Indonesia Tahun 2013. Bank Indonesia.

2015. Laporan Perekonomian Indonesia Tahun 2014. Bank Indonesia.

2016. Laporan Perekonomian Indonesia Tahun 2015. Bank Indonesia. 2017. Laporan Perekonomian Indonesia Tahun 2016. Bank Indonesia

2012. Laporan Tahunan Bank Indonesia 2011. Bank Indonesia.

Bank Negara Malaysia. 2015. Finacial Stability and Payment System Report 2015. Malaysia.

Bank of Thailand. 2015. Payment System Report. Thailand.

Ferry Syariffuddin, Ahmad Hidayat, dan Tarsidin. 2009. Dampak Peningkatan Pembayaran Non-tunai Terhadap Perekonomian dan Impikasinya Terhadap Pengendalian Moneter di Indonesia. Bank Indonesia. Jakarta.

Insukindro. 1999. Pemilihan dan Bentuk Fungsi Ekonomi Empirik dengan Pendekatan Koreksi Kesalahan. Jurnal Ekonomi dan Bisnis Indonesia. Vol. 14 No.1.

Lasondy Istanto, dan Syarief Fauzie. 2014. Analisis Dampak Pembayaran Non Tunai Terhadap Jumlah Uang Beredar
Di Indonesia. Jurnal Ekonomi dan Keuangan, Vol. 2. No. 10, Hal. 610621.

Layaman dan Novi Andriyani. 2017. Analisis Penggunaan Teknologi Informasi Serta Dampaknya Pada Kepuasan Nasabah Bank Jabar Banten Syariah Cirebon. Al-Amwal : Jurnal Ekonomi dan Perbankan Syari'ah, Vol. 9. No 1. Hal. 39-58

Mankiw, N. Gregory. 2006. Makroekonomi Edisi Keenam. Penerbit Erlangga. Jakarta.

Mbuguah, Samuel dan Karume, Simon. 2013. Trends In Electronic Money Transfer in Kenya. Journal of Emerging Trends in Computing and Information Sciences. Vol. 4, No. 1. Hal. 69-78. 2007. Makroekonomi Edisi Keenam. Penerbit Erlangga. Jakarta.

Muamar, Afif, \& Ari Salman Alparisi. "Electronic money (e-money) in maqashid al-sharia perspective." Journal of Islamic Economics Lariba [Online], 3.2 (2017): 75-84.

Mudrajad Kuncoro. 2006. Ekonomika Pembangunan: Teori, Masalah, dan Kebijakan. UPP STIM YKPN. Yogyakarta.

Nopirin. 1992. Ekonomi Moneter. BPFE UGM. Yogyakarta.

Rahman Helmi dan Zaki Mubarak. 2014. Analisis Faktor-Faktor yang Mempengaruhi Masyarakat Kalimantan Selatan Terhadap Penggunaan Pembayaran Non Tunai. Jurnal Studi Ekonomi, Vol. 5. No. 1.

Siti Hidayati, Ida Nuryanti, Agus Firmansyah, Aulia Fadly, dan Isnu Yuwana Darmawan. 2006. Kajian Operasional E-money. Bank Indonesia. Jakarta.

Solikin dan Suseno. 2002. Uang: Pengertian, Penciptaan, dan Peranannya dalam Perekonomian. Pusat Pendidikan dan Studi 
Kebanksentralan Bank Indonesia. Jakarta.

Suliman, Suliman Zakaria., Dafaalla, Hala Ahmed. 2011. An Econometric Analysis of Money Demand Function in Sudan, 1960 to 2010. Journal of Economics and International Finance. Vol. 3. No. 16, Hal. 793-800.

Suharsimi Arikunto. 2006. Prosedur Penelitian: Suatu Pendekatan Praktek, Edisi Revisi. PT. Rineka Cipta. Jakarta.

Sumolang, Richard Matias. 2015. Analisis Permintaan Uang Elektronik (EMoney) di Indonesia. Skripsi. Jurusan Ilmu Ekonomi Universitas Hasanuddin. Makasar. http://repository.unhas.ac.id/bitstream/ handle/123456789/17960/ANALISIS \%20PERMINTAAN\%20UANG\%20E LEKTRONIK\%20(EMONEY)\%20DI\%20INDONESIA \%2 0 \%20RICHARD\%20MATIAS\%20SU MOLANG\%20(A11111290).pdf?sequ ence=1, diakses 21 September 2018.

Syahirman Yusi. dan Umiyati Idris. 2009. Metodologi Penelitian Ilmu Sosial Pendekatan Kuantitatif. Citrabooks Indonesia. Palembang.

Todaro, Michael P. dan Smith, Stephen C. 2006. Pembangunan Ekonomi/Edisi Kesembilan, Jilid 1. Penerbit Erlangga. Jakarta.

Veithzal Rivai, Sofyan Basir, Sarwono Sudarto, dan Arifiandy Permata Veithzal. 2013. Commercial Bank Management: Manajemen Perbankan dari Teori ke Praktek. PT RajaGrafindo Persada. Jakarta. 